\title{
EFFECT OF MICROBIOLOGICAL TREATMENT ON THE NUTRITIVE VALUE OF CORN SILAGE
}

\author{
[17] \\ Abdalla $^{1}$, E.B., A.A.M. Abdelhafez ${ }^{2}$, Thanaa, F. Mohammed ${ }^{3}$, Aza, M. Badr ${ }^{3}$ and \\ E.M. El- Shahat ${ }^{3}$ \\ 1- Dept. of Animal Production, Fac. of Agric., Ain Shams Univ., Cairo, Egypt \\ 2- Dept. of Agricultural Microbiology, Fac. of Agric., Ain Shams Univ., Cairo, Egypt \\ 3- Regional Center for Feed and Food, Agricultural Research Center, Giza, Egypt \\ *Corresponding author, email: aabdekwahab@agr.asu.edu.eg
}

Keywords: Whole corn stalks, Silage, Lactobacillus plantarum, Entrococcus faecium, Microbiological treatment, Nutritive values, Digestibility, Nitrogen balance, Sheep

\section{ABSTRACT}

The current study aimed to investigate the effect of microbiological treatment on improving the nutritive value of corn silage as animal feed. Dried whole corn plants were prepared and two ground silos (0.5 ton each) were used for ensiling whole corn silage and inoculated by bacterial inoculant (containing Lactobacillus plantarum and Entrococcus faecium) at the recommended rate of $1 / 2 \mathrm{~g}$ bacterial inoculants/liter of water/ton of fresh whole corn silage. The ensiling period lasted for 50 days. The criteria of response were determined by: the quality of treated corn silage, chemical characteristics and performance of rams, nutrients digestibility and nitrogen balance. Results for treated and untreated silage, respectively, showed that the silage had $\mathrm{pH} 3.71$ and 3.69, Total Volatile Fatty Acids (TVFA) were 2.48 and $1.98 \mathrm{mmol} / 100 \mathrm{ml}$, and $\mathrm{NH}_{3}$ $\mathrm{N}$ values were $6.1 \%$ and $6.41 \%$ (on dry matter basis). The values of organic matter (OM), crude protein (CP), crude fiber (CF), ether extract (EE), nitrogen free extract (NFE) and ash content on dry matter basis, however, were very close in the two rations. There were no significant differences between the two rations for the dry matter (DM). The value of CF digestibility was not significantly different from that in treated corn silage, while ration contents of treated corn silage were significantly higher in OM, CP, NFE and EE digestibility than the untreated corn silage. Recorded values for total digestible nutrients (TDN) and starch value (SV) of rations of treated corn silage were significantly higher than those of untreated corn silage being 52.64 and 63.37 vs. 43.53 and $56.09 \%$, respectively. The digestible crude protein (DCP) values were $(7.43 \%)$ for ration of treated corn silage by $5.96 \%$ for the ration of untreated corn silage.

\section{INTRODUCTION}

In Egypt, corn stalks, at 3.6 million tons/year, are the major available source of lignocellulosic wastes, which can be collected from commercial research farms. Corn silage is a safe feed and the most popular with feeders, that is often called the "king of roughages" for animal rations. Moreover, it works well for starting cattle and lambs as feed, the corn plant can also be handled mechanically at convenient time of the year and over a short period of time. Well-made corn silage is a very palatable product with a moderate value of a digestible protein and particularly for the amount of energy contents. On a dry matter (DM) basis, corn silage usually has $8.9 \%$ crude protein, $65 \%$ to $75 \%$ TDN (Kellems and Church, 2001). Feeding with high quality silage can possibly increase animal performance, reduce feeding costs and, ultimately, results in an increased return in time and money invested in forage production. 
Van Saun (2000) indicated that the silage quality can greatly influence animal's productivity; the poorer silage quality, the longer it remains in the ruminant digestive tract, decreasing animal productivity. Moreover, ensiling process destroys the germination power of weeds. Animal organic wastes can be ensiled with green forage. The process of ensiling kills pathogenic bacteria, fungi and parasites if present in animal wastes. The process is less dependent on the weather. Silage furnishes high quality succulent feed for any season of the year at a low expense and the possibility for keeping more animals on a certain area of land.

Bacterial inoculants are the most widely and fastest growing class of silage additives today. Most contain live cultures of mainly lactic acid bacteria of the genera Lactobacillus, and Streptococcus, in addition to Pediococcus. These bacteria ferment sugar (glucose and fructose) to lactic acid. The increase in lactic acid causes the $\mathrm{pH}$ of the silage to drop rapidly; stabilizing the forage once $\mathrm{pH}$ gets near 4.0 is achieved. Wittenberg et al (1983) and Gordon (1989) indicated that few silage inoculants have been shown to hasten the fermentation process, resulting in less nutrient loss, improved digestibility, less protein breakdown and silage with higher feed quality.

The aim of the present study was evaluating the effect of bacterial treatment of Lactobacillus plantarum and Entrococcus faecium on the digestibility and feeding values of whole corn silage.

\section{MATERIALS AND METHODS}

Experiments of the current investigation were carried out at the Regional Center for Feed and Food (RCFF) of Agricultural Research Center (ARC) and at Faculty of Agriculture, Ain Shams University, Egypt. Corn plants were obtained from the experimental farm of Agricultural Research Center (ARC), Giza, to study the effect of microbiological treatment for improving nutritive value of corn silage.

\section{Preparation of corn silage}

Whole corn plants (at medium dough stage) were directly chopped into $2-3 \mathrm{~cm}$ pieces with forage chopping harvester machine. The ensiling process started immediately after chopping where moisture content at the ensilage process was approximately $70 \%$. The silage stocks were comprised by a tractor and tightly sealed by plastic sheets then hardly covered by $20 \mathrm{~cm}$ soil and rice straw boles to guarantee anaerobic conditions for good lactic acid fermentation. Two ground silos ( 0.5 ton each) were used for the experiment, one was untreated whole corn silage prepared without any additives and the second was composed of whole corn silage inoculated with Lactobacillus plantarum and dried Entrococcus faecium (1132 N63), obtained from Pioneer Company (Japan). Inoculation was conducted at the recommended rate of $1 / 2 \mathrm{~g}$ bacterial cells/ liter water/ ton of fresh whole corn silage. The ensiling lasted for 50 days, and then samples were taken to test quality. After the ensiling period, the whole corn silages were available for feeding animals in digestible trials.

\section{Determination of silage quality}

Silage $\mathrm{pH}$ was determined using digital $\mathrm{pH}$ meter. Ammonia nitrogen was determined using saturated solution of magnesium oxide and distillation was performed according to method of A.O.A.C. (1990). Total VFAs were determined according to Warner (1994).

\section{Metabolism trials}

To determine nutrient digestibility and nutritive value of the experimental rations, two digestible trials were conducted with three rams/group, with average weight of $73.5 \mathrm{Kg}$ for each ram. The formulation of the experimental rations is shown in Table (1). Each trial continued for 31 days, which 21 days were considered as preliminary period followed by 10 days as a collection period. Samples of feces were collected, mixed and then dried at $60^{\circ} \mathrm{C}$ for 48 hours. Dried feces were ground and stored for complete chemical analysis.

Table 1. Formulation of experimental rations fed in corn silage trials

\begin{tabular}{|c|c|c|}
\hline Ingredients & Control & $\begin{array}{c}\text { Tested } \\
\text { silage }\end{array}$ \\
\hline Concentrated feed mixture & $500 \mathrm{~g}$ & $500 \mathrm{~g}$ \\
\hline Untreated corn silage & $2000 \mathrm{~g}$ & 0 \\
\hline Treated corn silage & 0 & $2000 \mathrm{~g}$ \\
\hline
\end{tabular}

\section{Chemical analysis}

Chemical analysis of samples of the experimental rations and feces included determination of dry matter, crude protein, crude fiber, ether extract 
and ash; all were performed according to the methods of A.O.A.C. (1990). Urine was collected daily from each ram during the collection period in plastic container containing sulfuric acid $(10 \%)$ to prevent losses of ammonia-N. Daily urine volume was measured and $10 \%$ of the volume was taken in glass bottles and stored in refrigerator for nitrogen determination.

\section{Statistical analysis}

Statistical analysis was done using SAS program (1996).

\section{RESULTS AND DISCUSSION}

Table (2) shows chemical composition of treated silages and untreated. Records illustrate that treated silage was slightly higher than treated one in terms of DM, OM, CP, EF and NFE, whereas it was lower in $\mathrm{CF}$ and $\mathrm{ASH}$. These observations were similar to those obtained by Yacout (2001) and El-Saadany et al (2001).

Table 2. Chemical analysis of ingredients of rations used in metabolism trials

\begin{tabular}{|c|c|c|c|}
\hline Parameter & $\begin{array}{c}\text { Concentrated } \\
\text { ration }\end{array}$ & $\begin{array}{c}\text { Untreated } \\
\text { corn silage }\end{array}$ & $\begin{array}{c}\text { Treated } \\
\text { corn } \\
\text { silage }\end{array}$ \\
\hline DM & 90.66 & 32.48 & 33.24 \\
OM & 90.31 & 91.27 & 92.87 \\
CP & 15.67 & 7.73 & 8.60 \\
CF & 13.40 & 28.87 & 25.35 \\
EE & 2.64 & 1.74 & 2.21 \\
ASH & 9.69 & 8.73 & 7.13 \\
NFE & 58.61 & 52.92 & 56.71 \\
\hline
\end{tabular}

DM: dry matter, OM: organic matter, $\mathrm{CP}$ : crude protein, CF: crude fiber, EE: ether extract, NFE: nitrogen free extract

\section{Silage quality}

Results of silage quality determination (Table 3) showed that $\mathrm{pH}$ and $\mathrm{NH}_{3}-\mathrm{N}$ values did not significantly differ after treatment, while TVFA slightly decreased. These results were in disagreement with those obtained by Yacout (2001) and ElSaadany et al (2001). Generally, good quality silage should have $\mathrm{pH}$ between 3.8 and 4.20 (McDonald et al 1995 and EL-Shennawy 2003), but the TVFA's values were $2.48 \mathrm{mmol} / 100 \mathrm{ml}$ in treated corn silage compared with untreated corn silage $(1.98 \mathrm{~m} \mathrm{~mol} / 100 \mathrm{ml})$. Chemical composition of the experimental rations used during the whole experimental period is presented in Table (4).

Table 3. Effect of microbial inoculation on corn silage quality at the end of ensilage period

\begin{tabular}{|c|c|c|}
\hline Parameter & $\begin{array}{c}\text { Untreated } \\
\text { corn silage }\end{array}$ & $\begin{array}{c}\text { Treated } \\
\text { corn silage }\end{array}$ \\
\hline $\mathrm{pH}$ & 3.71 & 3.69 \\
$\mathrm{NH}_{3}-\mathrm{N}$ (as \% of & 6.10 & 6.41 \\
$\begin{array}{c}\text { DM) } \\
\text { Total VFA's } \\
(\mathrm{mmol} / 100 \mathrm{ml})\end{array}$ & 2.48 & 1.98 \\
\hline
\end{tabular}

Table 4. Chemical composition of the experimental rations used during the whole experimental period (\% on DM basis)

\begin{tabular}{|c|c|c|}
\hline Parameter & $\begin{array}{c}\text { Untreated corn } \\
\text { silage }\end{array}$ & $\begin{array}{c}\text { Treated corn } \\
\text { silage }\end{array}$ \\
\hline DM & 56.92 & 57.01 \\
OM & 89.23 & 91.10 \\
CP & 10.77 & 8.90 \\
CF & 10.40 & 11.32 \\
EE & 23.41 & 19.71 \\
ASH & 1.75 & 2.25 \\
NFE & 53.67 & 57.82 \\
\hline
\end{tabular}

\section{Digestibility coefficient}

Results concerning nutrient digestibility coefficients are presented in Table (5). The results indicated that there was a significant difference between the two rations concerning DM, OM, CP, EE and NFE digestibility in treated silage corn ration compared to untreated corn silage ration, the same result was obtained by El-Shennawy (2003). The average digestion coefficients of DM using different animal species and different varsities of corn silage ranged between 52.3 and 66.6\% (Block et al 1982 and Etman et al 1994). Ferret et al (1997) found that OM digestibility of different corn hybrid silages by sheep ranged from $59.2 \%$ to $75.7 \%$. The digestibility of CF of corn silage by different animal species ranged between $56.7 \%$ and $70.6 \%$ (Etman et al 1994 and El-Sayes et al 1997). The 
digestion coefficients of corn silage ranged between 74.96 and $80.62 \%$ for EE (Mahmoud et al 1992 and Gaafar, 2001) and ranged between 59.58 and $75.2 \%$ for NFE (Leahy et al 1981 and Gaafar, 2001).

Table 5. Effect of bacterial inoculants 1132 N631 on digestibility Coefficients of corn silage at the end of ensilage period (\% on DM)

\begin{tabular}{|c|c|c|}
\hline $\begin{array}{c}\text { Digestibility } \\
\text { coefficients }\end{array}$ & $\begin{array}{c}\text { Untreated } \\
\text { corn silage } \\
\text { ration }\end{array}$ & $\begin{array}{c}\text { Treated } \\
\text { corn silage } \\
\text { ration }\end{array}$ \\
\hline DMD & $62.48^{\mathrm{b}}$ & $70.14^{\mathrm{a}}$ \\
OMD & $60.98^{\mathrm{b}}$ & $66.88^{\mathrm{a}}$ \\
CPD & $57.26^{\mathrm{b}}$ & $65.65^{\mathrm{a}}$ \\
CFD & $54.30^{\mathrm{a}}$ & $55.98^{\mathrm{a}}$ \\
EED & $76.06^{\mathrm{b}}$ & $87.13^{\mathrm{a}}$ \\
NFED & $64.13^{\mathrm{b}}$ & $70.04^{\mathrm{a}}$ \\
\hline
\end{tabular}

Different superscripts $(a, b)$ indicate significant difference $(p<0.05)$.

\section{Nutritive value}

The nutritive value obtained for the different rations (on DM basis) in terms of total digestible nutrients (TDN \%), starch value (SV) and digestible crude protein (DCP \%) are presented in Table (6). These values were significantly higher in treated corn silage ration than in control ration. Starch value of treated corn silage rations reached $52.64 \%$ compared with untreated corn silage (control) which was $43.53 \%$. Moreover, the TDN value increased in treated corn silage to $63.37 \%$ where in untreated corn silage ration was $56.09 \%$. These results were in agreement with those obtained by Mahmoud et al (1992). Also, the DCP increased in treated corn silage rations to $7.43 \%$ compared with untreated corn silage rations (5.96\%). However, El-Sayes et al (1997) and Mohamed et al (1999) mentioned that TDN was higher and DCP was lower in the rations contained treated corn silage than the untreated corn silage. It could be concluded that the quality of corn silage can be improved when treated with effective fermentative bacterial species. Corn silage usually has $65-75$ $\%$ TDN (Church, 1991). Average DCP values of corn silage ranged between 4.40 and $7.87 \%$ as reported by El-Sayes et al (1997) and Etman et al (1994).
Table 6. Nutritive values (\% on DM basis) of silage untreated with bacterial inoculants 1132 N 631 at the end of ensilage period

\begin{tabular}{|c|c|c|}
\hline $\begin{array}{c}\text { Nutrient } \\
\text { value }\end{array}$ & $\begin{array}{c}\text { Untreated corn } \\
\text { silage ration }\end{array}$ & $\begin{array}{c}\text { Treated corn } \\
\text { silage ration }\end{array}$ \\
\hline SV & $43.53^{\mathrm{b}}$ & $52.64^{\mathrm{a}}$ \\
TDN & $56.09^{\mathrm{b}}$ & $63.37^{\mathrm{a}}$ \\
DCP & $5.96^{\mathrm{b}}$ & $7.43^{\mathrm{a}}$ \\
\hline
\end{tabular}

Different superscripts $(a, b)$ indicate significant difference $(p<0.05)$.

\section{Nitrogen balance}

It was clear that nitrogen intake values recorded for animals fed on treated corn silage ration was significantly $(p<0.05)$ higher than those fed on untreated corn silage ration (Table 7 ). Nitrogen balance $(\mathrm{g} / \mathrm{h} / \mathrm{d})$ was positive in treated corn silage ration and untreated corn silage rations indicating that the animals were in normal nitrogen metabolism status, a condition necessary for accurate evaluation of the tested rations. Similar results have been reported by El-Kady et al (1999), Abd El-Rahman (1996) and El-Shennawy, (2003). They mentioned that feeding sheep or goats with either treated silage or untreated silage improved retained nitrogen. Concerning nitrogen retained (\%) from nitrogen intake, it could be noticed that values recorded for sheep given treated corn silage ration were higher than those recorded for animals given the untreated ration.

Table 7. Nitrogen utilization with rams fed on the experimental rations

\begin{tabular}{|c|c|c|}
\hline Items & $\begin{array}{c}\text { Untreated } \\
\text { corn silage } \\
\text { ration }\end{array}$ & $\begin{array}{c}\text { Treated } \\
\text { corn silage } \\
\text { ration }\end{array}$ \\
\hline $\begin{array}{c}\text { Nitrogen intake } \\
\text { (g/h/day) }\end{array}$ & $17.74^{\mathrm{b}}$ & $19.24^{\mathrm{a}}$ \\
$\begin{array}{c}\text { Nitrogen extraction } \\
\text { (g/h/day): }\end{array}$ & \\
Fecal- N & $7.56^{\mathrm{a}}$ & $6.6^{\mathrm{b}}$ \\
Urinary-N & $4.72^{\mathrm{a}}$ & $4.7^{\mathrm{a}}$ \\
Digested-N & $10.18^{\mathrm{b}}$ & $12.46^{\mathrm{a}}$ \\
Nitrogen retention & $5.46^{\mathrm{b}}$ & $7.94^{\mathrm{a}}$ \\
( g/h/day) & $30.78^{\mathrm{b}}$ & $41.27^{\mathrm{a}}$ \\
$\%$ of N-intake & $53.63^{\mathrm{b}}$ & $63.72^{\mathrm{a}}$ \\
\hline$\%$ of N-digested & 5
\end{tabular}

Different superscripts $(a, b)$ indicate significant difference $(p<0.05)$. 
Generally, rams fed on treated silage tended to perform better than those fed on untreated silage and have the lowest feed cost $/ \mathrm{kg}$ gain (LE). From the foregoing results, it could be concluded that preserving amount of corn plant as silage treated with lactic acid bacteria has a beneficial effect in offering an appropriate ruminal condition, enhancing animal performance and reduced the feed cost of $\mathrm{kg}$ gain and participate in feeding animal and minimize such problems of disposal pollution. These results introduce an effective technique towards making best use of residues which is applicable on medium sized farms to upgrade lignocelluloses agricultural wastes in such a way that can be used by small holders as fodder for ruminants. More research is needed for making silage from other kinds of residues and on other species and breeds of animals.

\section{REFERENCES}

Abd El-Rahman, H.H. 1996. Utilization of desert range poor quality feed by sheep and goats. M.Sc. Thesis, Fac. of Agric., Cairo University. Egypt.

A.O.A.C. 1990. Association of Official Analytical Chemists, Official Methods of Analysis. $15^{\text {th }} \mathrm{Ed}$, Washington D.C., USA.

Block, E., Muller, L.D. and Kilmer, L.H. 1982. Brown midrib-3 versus Normal corn plant (Zea maize $L$.) harvested as whole plant or Stover. Cand. J. Anim. Sci. 62(2): 487-498.

Church, D.D. (1991). Livestock feeds and feeding. $3^{\text {rd }}$ Ed. Prentice Hall Inc. Englewood Cliffs, New Jersey, USA.

El-Kady, R.I.M., Mohamed, M.I. and Shoukry, M.M. 1999. Utilization of sugar beet tops as fresh, hay and silage by sheep. J. Agric. Sci., Mansoura University, 24: 6427-6435.

El-Saadany, S.A., Abd El-Khader, M., Mohamed, B.K. and Zeid, A.M. 2001. Comparative study on the effect of feeding maize stalks silage or whole maize plants silage versus traditional rations on crossbred Friesian lactating cows. Egyptian J. Nutrition and Feeds. 4 (Special Issue): 337-343.

El-Sayes, M.F., Mostafa, M.R.M. and Hathout, M.K. 1997. Nutritional and economical efficiency for using the maize silage in fattening buffalo calves locally. Proceedings of the $5^{\text {th }}$ world buffalo Congress, Caserta, Italy. October 13-16, 1997, pp. 386-390.
El-Shennawy, A. 2003. Studies on silage in ruminants feeding. M.Sc. Thesis, Fac of Agric. Cairo University, Egypt.

Etman, G.L., Khafagi, E.A., Abd EI-Malik, W.H., Hathout, M.K. and El-Sayes, M.F. 1994. Conserving of green growing lambs. Egyptian J. Anim. Prod., 31: 175-179.

Ferret, A., Gase, J., Plaixats, J., Casanas, F., Bosch, L. and Nuez, F. 1997. Prediction of voluntary intake and digestibility of maize silages given to sheep from morphological and chemical composition, in vitro digestibility or rumen degradation characteristics. J. Anim. Sci., 64: 493-501.

Gaafar, H.M. 2001. Performance of growing calves fed rations containing corn silage. Ph.D. Thesis, Fac. Agric., Tanta University, Egypt.

Gordon, F.J. 1989. An evaluation through lactating cattle of a bacterial inoculant as an additive for grass silage. Grass and Forage Science. 44(2): 169-179.

Kellems, R.O. and Church, D.C. 2001. Livestock feeds and feeding. $5^{\text {th }}$ Edition, Prentice Hall, New Jersey, USA.

Leahy, K.T., Barth, K.M., Fulgoni, V.L. and Howard, D.D. 1981. Effect of corn silage additives on digestibility and dry matter recovery. J. Anim. Sci., 53: 382-388.

Mahmoud, A.M., Bendary, M., Harfoush, M.A. and Ramadan, G.A. 1992. Effect of feeding lactating cows' corn silage on milk production compared with traditional summer and winter rations. J. Agric. Sci. Mansoura University, 17: 2904-11.

McDonald, P., Edwards, R.A., Green Halgh, J.F.D. and Morgan, C.A. 1995. Animal nutrition $5^{\text {th }}$ Ed., Copyright licensing LTD., London. Benjamin-Cummings Publishing Company.

Mohamed, M.M., Ahmed, S.M.M. and Bendary, M.M. 1999. Productive and reproductive performance of growing calves feed rations containing maize silage. Egyptian J. Nutrition and Feed, 2 (special issue): 445-

SAS. Statistical Analysis System. 1996. SAS Institute, Cary, NC, USA.

Van Saun, R. 2000. Evaluating silage quality. November 2000. Health Memo. Pennsylvania State Univ., Vetr. Sci. Extension.

Warner, A.C.I. 1994. Production of volatile fatty acids in the rumen: method of measurement. Nutr. Abstract and Review, 34: 339-352. 
Wittenberg, K.M., Ingalls, J.R. and Devlin, T. 1983. The effect of lactobacteria inoculation on corn silage preservation and feeding value for growing beef animals and lambs. Can. J. Anim. Sci., 63: 917-924.
Yacout, M.H.M. 2001. Fermentation characteristics and feed value of inoculants and ammonia treated corn silage. $2^{\text {nd }}$ International Conference on Animal Production and Health in SemiArid Areas: 205-211. 